\title{
ANALISIS PENGARUH HARGA DAN KEMASAN PRODUK TERHADAP KEPUTUSAN PEMBELIAN
}

\section{The Influence of Prices and Brand Packaging on Purchasing Decisions}

\author{
Yandri Sudodo \\ Program Studi Manajemen, Fakultas Ekonomi dan Bisnis, Universitas Teknologi Sumbawa \\ e-mail : yandri.sudodo@uts.ac.id
}

\begin{abstract}
The purpose of this study was to find out and analyze whether the price factor $\left(X_{1}\right)$ and product packaging $\left(X_{2}\right)$ had an influence on purchasing decisions $(Y)$ in UMKM Products in Jotang Beru Village, and to find out which of the most influential product price and packaging variables. The results of the analysis using SPSS (Statistical Program and Services Solution) version 23 show that the results of the regression coefficient $Y=3.408+0.418 X_{1}+0.421 X_{2}$ indicate the price variable $\left(X_{1}=0.418\right)$, and product packaging $\left(X_{2}=0.421\right)$. The value of $R_{\text {Square }}($ Determination Coefficient) is 0.413 . Simultaneous test results (Test $F$ ) show that together the product price and packaging variables have a significant effect on purchasing decisions on UMKM products in Jotang Beru Village in Empang District. The partial test results ( $t$ test) show that from the two variables $X$ namely the price and product packaging the most significant effect on purchasing decisions is product packaging. Suggestions for UMKMs in Jotang Beru Village are to continue to improve and maintain product pricing and packaging strategies because these variables have an influence on purchasing decisions as much as $41.3 \%$.
\end{abstract}

\begin{abstract}
ABSTRAK
Tujuan penelitian ini adalah untuk mengetahui dan menganalisis apakah faktor harga $\left(\mathrm{X}_{1}\right)$ dan kemasan produk $\left(\mathrm{X}_{2}\right)$ memiliki pengaruh terhadap keputusan pembelian (Y) di Produk UMKM Desa Jotang Beru, serta untuk mengetahui manakah diantara variabel harga dan variabel kemasan produk yang paling berpengaruh. Hasil analisis dengan menggunakan SPSS (Statistical Program and Services Solution) versi 23 menunjukkan bahwa dari hasil koefisien regresi $\mathrm{Y}=3,408+0,418 \mathrm{X}_{1}+0,421 \mathrm{X}_{2}$ menunjukkan variabel harga $\left(\mathrm{X}_{1}=0.418\right)$, dan kemasan produk $\left(\mathrm{X}_{2}=0.421\right.$ ). Nilai $\mathrm{R}$ square (Koefisien Determinasi) sebesar 0,413 . Hasil uji simultan (Uji $\mathrm{F}$ ) menunjukkan bahwa secara bersama-sama variabel harga dan kemasan produk berpengaruh signifikan terhadap keputusan pembelian pada produk UMKM Desa Jotang Beru di Kecamatan Empang. Hasil uji parsial (Uji t) menunjukkan bahwa dari kedua variabel X yakni harga dan kemasan produk yang paling berpengaruh signifikan terhadap keputusan pembelian adalah kemasan produk. Saran bagi pihak UMKM Desa Jotang Beru adalah terus meningkatkan dan mempertahankan strategi harga dan kemasan produk karena variabel ini mempunyai pengaruh terhadap keputusan pembelian sebanyak $41.3 \%$.
\end{abstract}

Kata Kunci : Harga, Kemasan Produk, Keputusan Pembelian

\section{Pendahuluan}

Harga merupakan salah satu faktor untuk menentukan keputusan pembelian. Pengaruh harga terhadap keputusan pembelian sangatlah penting karena dengan tingkat harga yang ditetapkan oleh perusahaan dapat menjadi tolak ukur akan permintaan suatu produk. Penetapan harga yang salah dalam suatu produk dapat mengakibatkan jumlah penjualan pada suatu produk tidak dapat maksimal yang mengakibatkan penjualan menurun dan pangsa pasarnya berkurang, (Alma, 2016). Oleh sebab itu, perusahaan harus dapat menentukan harga penjualan sesuai dengan pangsa pasar yang dituju agar penjualan produk dan pangsa pasar meningkat.

Kemasan produk juga merupakan suatu faktor yang menetukan keputusan pembelian. Pengaruh kemasan produk terhadap keputusan pembelian sangatlah penting karena pada dasarnya kemasan produk merupakan suatu bentuk penilaian dari konsumen terhadap gambaran yang diterima dengan informasi yang diberikan perusahan atau karyawan kepada konsumen, kemasan produk yang baik dan sesuai dengan kebutuhan dan keinginan konsumen, serta sesuai dengan trend dan mode yang kekinian turut berperan dalam memengaruhi keputusan pembelian. (Kotler \& Keller, 2009).

Ketika suatu kegiatan usaha mampu menangkap dan mengartikan apa yang diinginkan oleh seorang pelanggan, otomatis akan membuat para penggerak UMKM untuk meningkatkan kualitas mereka, baik dari segi peningkatan kemasan produknya bahkan peningkatan kualitas dari segi harga, dengan harapan agar para pelanggannya tidak berpindah ke pesaing. (Umar, 2010). 
Berdasarkan uraian di atas peneliti tertarik untuk melakukan penelitian "Analisis Pengaruh Harga dan Kemasan Produk Terhadap Keputusan Pembelian (Produk UMKM Desa Jotang Beru)"

Tujuan dari penelitian ini dapat adalah sebagai berikut :

1. Untuk mengetahui pengaruh harga secara parsial terhadap keputusan pembelian pada Produk UMKM Desa Jotang Beru.

2. Untuk mengetahui pengaruh kemasan produk secara parsial terhadap keputusan pembelian pada Produk UMKM Desa Jotang Beru.

3. Untuk mengetahui pengaruh harga dan kemasan produk secara simultan terhadap keputusan pembelian pada Produk UMKM Desa Jotang Beru.

\section{Metode Penelitian}

Dalam penelitian ini, penulis menggunakan metode penelitian deskriptif kuantitatif. Penelitian diskriptif adalah penelitian yang dilakukan untuk mengetahui nilai variabel mandiri, baik satu variabel atau lebih (independen) tanpa membuat perbandingan atau menghubungkan dengan variabel yang lain (Sugiyono, 2013). Menurut Sugiyono, (2013) Penelitian Kuantitatif, adalah penelitian dengan memperoleh data yang berbentuk angka atau data kualitatif yang diangketkan.

Data yang digunakan dalam penelitian ini adalah data primer, yaitu data yang bersumber dari penyebaran kuisioner terhadap konsumen yang bertransaksi membeli produk UMKM Desa Jotang Beru untuk mengetahui penilaian 2 faktor bersaing (harga dan kualitas kemasan produk) yang menimbukan keputusan pembelian pada konsumen. Data primer yang dikumpulkan meliputi; tanggapan konsumen tentang harga dan kemasan produk yang dijual oleh UMKM Desa Jotang Beru.

Kemudian teknik analisa data yang digunakan yaitu observasi, kuisioner, wawancara dan studi pustaka:

a. Observasi

Observasi adalah tekhnik pengumpulan data dengan mengadakan pengamatan - pengamatan secara langsung pada pelaksanaan operasi perusahaan atau instansi (Lesut, 2015). Berdasarkan keterlibatan dan penelitian yang dilakukan, peneliti menggunakan jenis observasi tak berstruktur yang merupakan observasi dimana pengamat atau peneliti melaksanakan pengamatan dengan bebas.

b. Kuisioner

Merupakan teknik pengumpulan data yang dilakukan dengan cara memberi seperangkat pertanyaan atau pernyataan tertulis kepada responden untuk dijawabnya, (Sugiyono, 2013). Kuisioner yang telah dibuat peneliti kemudian disebar di kalangan konsumen dari produk UMKM Desa Jotang Beru. c. Wawancara

Pengumpulan data yang dilakukan dengan cara melakukan wawancara langsung dengan responden secara sistematis sesuai tujuan penelitian. Selain itu juga dapat dilaksanakan dengan metode wawancara langsung (interview) kepada pihak yang berkepentingan yang bertujuan untuk mengetahui gambaran umum UMKM, terkait dengan sejarah, struktur pengurus, strategi dan lain sebagainya.

d. Studi Pustaka

Studi pustaka dilakukan dengan mempelajari dan mengambi data dari literarut terkait dan sumber-sumber lain yang dianggap dapat memberikan informasi mengenai penelitian ini.

\section{Hasil dan Pembahasan}

\section{Uji Kualitas Data}

Uji Validitas

Uji Validitas dilakukan dengan membandingkan nilai $\mathrm{r}_{\text {hitung }}$ dengan $r_{\text {tabel }}$, Dengan membandingkan nilai $r_{\text {hitung dari hasil }}$ output (Corrected Item-Total Correlation) dengan $\mathrm{r}_{\text {tabel, }}$ jika $\mathrm{r}_{\text {hitung }}$ lebih besar dari $\mathrm{r}_{\text {tabel }}$ maka butir pertanyaan tersebut adalah

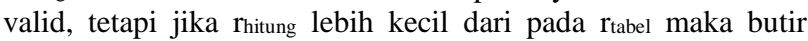
pertanyaan tersebut tidak valid (Ghozali, 2009). Untuk mendapatkan data primer, penulis melakukan penyebaran kuesioner kepada responden sebanyak 70 responden. Sebelum kuesioner disebarkan kepada 70 responden, penulis melakukan try out kepada 30 responden dengan memberikan 17 butir pertanyaan. Berikut ini adalah hasil perhitungan validitas, yaitu :

$R_{\text {hitung }}>R_{\text {tabel }}$ pada nilai signifikansi $5 \%=$ valid

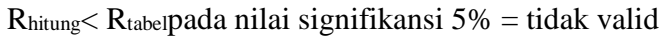

Tabel 1. Uji Validitas variabel harga $\left(\mathrm{X}_{1}\right)$

\begin{tabular}{cccc}
\hline No. item & $\mathrm{r}_{\text {hitung }}$ & $\mathrm{r}_{\text {tabel }}$ & Keterangan \\
\hline 1 & 0,644 & 0,361 & Valid \\
2 & 0,583 & 0,361 & Valid \\
3 & 0,716 & 0,361 & Valid \\
4 & 0,527 & 0,361 & Valid \\
5 & 0,703 & 0,361 & Valid \\
\hline
\end{tabular}

Sumber ; Data diolah, 2019

Tabel 2. Uji Validitas variabel kemasan produk $\left(\mathrm{X}_{2}\right)$

\begin{tabular}{cccc}
\hline No. item & $\mathrm{r}_{\text {hitung }}$ & $\mathrm{r}_{\text {tabel }}$ & Keterangan \\
\hline 1 & 0,743 & 0,361 & Valid \\
2 & 0,819 & 0,361 & Valid \\
3 & 0,809 & 0,361 & Valid \\
4 & 0,717 & 0,361 & Valid \\
5 & 0,792 & 0,361 & Valid \\
6 & 0,495 & 0,361 & Valid \\
\hline
\end{tabular}

Sumber ; Data diolah, 2019 
Tabel 3. Uji Validitas variabel keputusan pembelian (Y)

\begin{tabular}{cccc}
\hline No. item & $\mathrm{r}_{\text {hitung }}$ & $\mathrm{r}_{\text {tabel }}$ & Keterangan \\
\hline 1 & 0,609 & 0,361 & Valid \\
2 & 0,601 & 0,361 & Valid \\
3 & 0,711 & 0,361 & Valid \\
4 & 0,847 & 0,361 & Valid \\
5 & 0,740 & 0,361 & Valid \\
6 & 0,824 & 0,361 & Valid \\
\hline
\end{tabular}

Sumber ; Data diolah, 2019

Dari hasil uji yang dilakukan, semua pernyataan pada kuesioner tersebut adalah valid.

\section{Uji Reliabilitas}

Setelah menentukan validitas instrumen penelitian, tahap selanjutnya adalah mengukur reliabilitas data dari instrumen penelitian. Uji ini mengukur ketepatan alat ukur. Suatu alat ukur disebut memiliki reliabilitas yang tinggi jika alat ukur yang digunakan stabil. Pengujian reliabilitas dalam penelitian ini untuk menunjukkan konsistensi suatu alat pengukur dalam penelitian melalui nilai cronbach alpha karena menggunakan jenis data likert/essay. Teknik ini dapat menafsirkan korelasi antara skala diukur dengan semua variabel yang ada (Umar, 2010). Dalam pengujian reliabilitas ini, peneliti menggunakan metode statistik Cronbach Alpha dengan signifikansi yang digunakan sebesar 0,5 dimana jika nilai Cronbach Alpha dari suatu variabel lebih besar dari 0,5 maka butir pertanyaan yang diajukan dalam pengukuran instrumen tersebut memiliki reliabilitas yang memadai. Sebaliknya, jika nilai Cronbach Alpha dari suatu variabel lebih kecil dari 0,5 maka butir pertanyaan tersebut tidak reliabel (Ghozali, 2009). Pendapat lain menurut Bhuono (2005) uji reliabilitas dilakukan dengan melihat nilai Cronbach's Alpha dengan kriteria jika nilai Cronbach's Alpha > 0,5 maka suatu instrumen dikatakan reliabel dan Jika nilai Cronbach's Alpha < 0,5 maka suatu instrumen dikatakan tidak reliabel. Adapun hasil dari uji reliabilitas dapat dilihat pada tabel di bawah ini :

Tabel 4. Tabel Uji Reliabilitas

\begin{tabular}{cccc}
\hline Variabel & Cronbach's Alpha & $\begin{array}{c}\mathrm{r}_{\text {tabel }} 5 \% \\
(30)\end{array}$ & Ket \\
\hline $\mathrm{X}_{1}$ & 0,612 & 0,361 & Reliabel \\
$\mathrm{X}_{2}$ & 0,821 & 0,361 & Reliabel \\
$\mathrm{Y}$ & 0,806 & 0,361 & Reliabel \\
\hline
\end{tabular}

Sumber ; Data diolah, 2019

\section{Uji Asumsi Klasik}

\section{Uji Normalitas}

Data-data bertipe skala sebagai pada umumnya mengikuti asumsi distribusi normal. Namun, tidak mustahil suatu data tidak mengikuti asumsi normalitas. Untuk mengetahui kepastian sebaran data yang diperoleh harus dilakukan uji normalitas terhadap data yang bersangkutan. Dengan demikian, analisis statistika yang pertama harus digunakan dalam rangka analisis data adalah analisis statistik berupa uji normalitas. Menurut Ghozali (2009) uji normalitas bertujuan untuk mengetahui apakah dalam model regresi variabel dependen (terikat) dan variabel independen (bebas) mempunyai kontribusi atau tidak.

Salah satu cara termudah untuk melihat normalitas residual adalah dengan melihat grafik histogram yang membandingkan antara data observasi dengan distribusi yang mendeteksi distribusi normal. Namun demikian hanya dengan melihat histogram hal ini dapat menyesatkan khususnya untuk jumlah sampel yang kecil. Metode yang lebih handal adalah dengan melihat normal probability plot yang membandingkan distribusi kumulatif dari distribusi normal. Distribusi normal akan membentuk suatu garis lurus diagonal dan ploting data residual akan dibandingkan dengan garis diagonal (Ghozali, 2009). Adapun hasil perhitungan uji normalitas ditunjukan pada gambar grafik p-plot berikut :

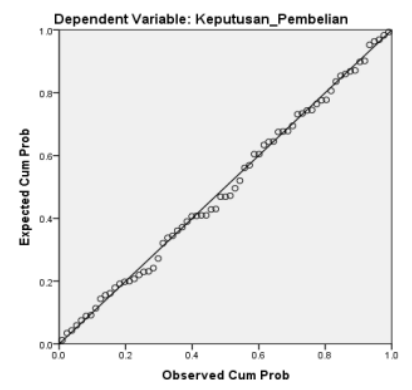

Gambar 1. Grafik p-p plot

Pada grafik normal plot terlihat titik-titik menyebar di sekitar garis diagonal, serta penyebarannya mengikuti arah garis diagonal. Kedua grafik ini menunjukkan bahwa model regresi layak dipakai karena asumsi normalitas (Ghozali 2009).

\section{Uji Multikolinearitas}

Pengujian multikolonieritas dilakukan untuk menguji apakah pada model regresi ditemukan adanya korelasi antar variabel independen. Untuk mendeteksi adanya problem multikol, maka dapat dilakukan dengan melihat nilai Tolerance dan Variance Inflation Factor (VIF) serta besaran korelasi antar variabel independen

Tabel 5. Uji Multikolinieritas

\begin{tabular}{lll}
\hline Variabel Penelitian & VIF & Tolerance \\
\hline Harga $\left(\mathrm{X}_{1}\right)$ & 1.175 & $0,851(85,1)$ \\
Kemasan $\left(\mathrm{X}_{2}\right)$ & 1.175 & $0,851(85,1)$ \\
\hline
\end{tabular}

Sumber : Data diolah, 2019

Tabel di atas menjelaskan bahwa data yang ada tidak terjadi gejala multikolinearitas antara masing-masing variabel independen yaitu dengan melihat nilai VIF. Nilai VIF yang diperbolehkan hanya mencapai 10 maka data di atas dapat dipastikan tidak terjadi gejala multikolinearitas. Karena data di atas menunjukan bahwa nilai VIF lebih kecil dari 10 dan nilai tolerance lebih besar dari 0,10 keadaan seperti itu membuktikan tidak terjadinya multikolinearitas.

\section{Uji Heteroskedastisitas}

Uji heteroskedastisitas bertujuan untuk menguji apakah dalam model regresi terjadi ketidaksamaan varians dari residual satu pengamatan yang lain. Heteroskedastisitas menunjukan bahwa 
variasi variabel tidak sama untuk semua pengamatan. Pada heterokedastisitas kesalahan yang terjadi tidak secara acak tetapi menunjukan hubungan yang sistematis sesuai dengan besarnya satu atau lebih variabel. Berdasarkan hasil pengolahan data, maka hasil Scatterplot dapat dilihat pada gambar di bawah ini :

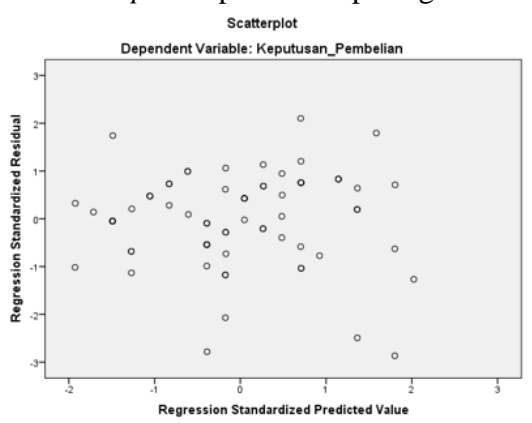

Gambar 2. Grafik Scatterplot

Dari grafik scatterplot yang ada pada gambar di atas dapat dilihat bahwa titik-titik menyebar secara acak, serta tersebar baik di atas maupun dibawah angka nol pada sumbu Y. Hal ini dapat dikatakan bahwa tidak terjadi heteroskedastisitas pada model regresi. (Ghozali, 2009).

\section{Analisis Regresi Linier Berganda}

\section{Hasil Uji Persamaan Regresi Linier Berganda}

Analisis regresi linier berganda digunakan untuk mengetahui pengaruh antara variabel independen terhadap variabel dependen, adapun hasil uji regresi linier berganda bisa dilihat pada tabel di bawah ini:

Tabel 6. Hasil Uji Regresi Linier Berganda

\begin{tabular}{ll}
\hline $\begin{array}{l}\text { Unstandardized } \\
\text { Coefficients }\end{array}$ & $\begin{array}{l}\text { Standardized } \\
\text { Coefficients }\end{array}$ \\
\hline
\end{tabular}

\begin{tabular}{llrrr}
\multicolumn{1}{l}{ Model } & \multicolumn{2}{c}{ Std. Error } & Beta & \\
\hline 1 & (Constant) & 3.408 & 2.482 & \\
& Harga & .418 & .118 & .354 \\
& Kemasan & .421 & .097 & .432 \\
\hline
\end{tabular}

Sumber : Data diolah, 2019

Berdasarkan hasil yang telah diperoleh dari koefisien regresi di atas, maka dapat dibuat suatu persamaan regresi sebagai berikut:

$$
\mathrm{Y}=3,408+0,418 \mathrm{X}_{1}+0,421 \mathrm{X}_{2}
$$

Dari persamaan di atas dikatakan bahwa varibel $\mathrm{X}_{1}$ mempunyai pengaruh sebesar 0,418 terhadap variabel $\mathrm{Y}$, dan variabel $\mathrm{X}_{2}$ mempunyai pengaruh sebesar 0,421 terhadap variabel Y. Setiap kenaikan nilai variabel $\mathrm{X}_{1}$ sebesar 0.418 maka mempunyai pengaruh sebanyak $1 \%$ terhadap variabel $\mathrm{Y}$. begitu pula pada varibel $\mathrm{X}_{2}$, setiap kenaikan sebanyak 0,421 maka akan mempengaruhi variabel Y sebanyak $1 \%$.

\section{Hasil Uji Determinasi (Adjusted $\mathbf{R}_{2}$ )}

Menurut Ghazali (2009) untuk menentukan seberapa besar variabel independen dapat menjelaskan variabel dependen, maka perlu diketahui nilai koefisien determinasi (Adjusted $R_{\text {Square }}$ ). Adapun hasil uji determinasi Adjusted $R_{2}$ dapat dilihat pada tabel berikut:

\begin{tabular}{|c|c|c|c|c|}
\hline Model & $\mathrm{R}$ & $\begin{array}{l}\text { Adjusted } \\
\text { R Square Square }\end{array}$ & $\begin{array}{l}\text { R Std. Error } \\
\text { Estimate }\end{array}$ & of the \\
\hline 1 & $.656^{\mathrm{a}}$ & .430 & .413 & 2.23372 \\
\hline
\end{tabular}

Berdasarkan tabel di atas diketahui nilai Adjusted $R_{\text {Square }}$ sebesar 0,413 (41,3\%), ini menunjukkan bahwa dengan menggunakan model regresi yang didapatkan dimana variabel independen yaitu harga dan kemasan produk memiliki pengaruh terhadap variabel keputusan pembelian sebesar $41,3 \%$. Sedangkan sisanya $58,7 \%$ dijelaskan dengan faktor atau variabel lain yang tidak diketahui dan tidak termasuk dalam analisis regresi ini seperti promosi,saluran distribusi dll.

\section{Pengujian Hipotesis}

\section{Hasil Uji F (Pengujian Secara Simultan)}

Pengujian ini bertujuan untuk membuktikan apakah variabel variabel independen secara simultan (bersama-sama) mempunyai pengaruh terhadap variabel dependen (Ghozali, 2009). Hasil uji statistik F dapat dilihat di bawah ini :

Tabel 7. Hasil Uji F

\begin{tabular}{lrrrrr}
\hline Model & Sum of Squares & Df & Mean Square & F & Sig. \\
\hline 1 Regression & 252.574 & 2 & 126.287 & 25.311 & $.000^{\mathrm{a}}$ \\
Residual & 334.297 & 67 & 4.990 & \\
Total & 586.871 & 69 & & & \\
a. Predictors: (Constant), Harga, Kemasan Produk & & \\
b. Dependent Variable: keputusan pembelian & & \\
\hline
\end{tabular}

Kriteria Pengujian :

a. Jika nilai sig $<0,05$ atau $F_{\text {hitung }}>F_{\text {tabel }}$ maka terdapat pengaruh variabel $\mathrm{X}$ secara simultan terhadap variabel $\mathrm{Y}$

b. Jika nilai sig $>0,05$ atau $F_{\text {hitung }}<F_{\text {tabel }}$ maka tidak terdapat pengaruh variabel $\mathrm{X}$ secara simultan terhadap variabel Y

Dari tabel uji $\mathrm{F}$ di atas dapat dilihat bahwa nilai signifikansi adalah 0.00 kurang dari 0.05 dan nilai $F_{\text {hitung }}$ lebih besar dari $F_{\text {tabel }}$ yakni $25.311>313$. maka dapat disimpulkan bahwa terdapat pengaruh variabel $\mathrm{X}$ secara simultan terhadap variabel $\mathrm{Y}$.

\section{Hasil Uji t (Pengujian Secara Parsial)}

Uji t menunjukkan ada atau tidaknya pengaruh satu variabel penjelas atau independen secara individual dalam menerangkan variasi variabel dependen dan digunakan untuk mengetahui ada atau tidaknya pengaruh masing-masing variabel independen secara individual terhadap variabel dependen yang diuji pada tingkat signifikansi 0,05 (Ghozali, 2009). 
Tabel 8. Hasil Uji t

\begin{tabular}{|c|c|c|}
\hline Variabel bebas & $t_{\text {hitung }}$ & Signifikansi \\
\hline Harga & 3.543 & 0.001 \\
\hline Kemasan Produk & 4.323 & 0.000 \\
\hline
\end{tabular}

Sumber : Data diolah, 2019

Berdasarkan tabel di atas dapat dilihat bahwa pengaruh harga dan kemasan produk terhadap keputusan pembelian menunjukkan pengaruh yang signifikan. Berikut ini adalah hasil penjelasan mengenai pengaruh antar variabel independen terhadap keputusan pembelian:

a. Pengaruh Harga Terhadap Keputusan Pembelian

Diketahui nilai sig. untuk pengaruh harga $\left(\mathrm{X}_{1}\right)$ terhadap Keputusan Pembelian (Y) adalah sebesar $0.001<0.05$ dan nilai thitung lebih besar dari tabel yakni $3.543>1.996$, sehingga dapat disimpulkan bahwa $\mathrm{H}_{1}$ diterima, yang berarti harga $\left(\mathrm{X}_{1}\right)$ mempunyai pengaruh secara parsial terhadap variabel $\mathrm{Y}$.

b. Pengaruh Kemasan Produk Terhadap Keputusan Pembelian

Nilai sig. untuk pengaruh Kemasan Produk $\left(\mathrm{X}_{2}\right)$ terhadap Keputusan Pembelian (Y) adalah sebesar $0.000<$ 0.05 dan nilai thitung lebih besar dari tabel yakni $4.323>1.996$, sehingga dapat disimpulkan bahwa $\mathrm{H}_{2}$ diterima, yang berarti Kemasan Produk $\left(\mathrm{X}_{2}\right)$ mempunyai pengaruh secara parsial terhadap variabel $\mathrm{Y}$.

\section{Kesimpulan}

Berdasarkan pada hasil penelitian dan pembahasan mengenai analisis pengaruh harga dan Kemasan Produk terhadap keputusan pembelian, maka penulis dapat menarik beberapa kesimpulan sebagai berikut:

1. Diketahui nilai sig. untuk pengaruh harga $\left(\mathrm{X}_{1}\right)$ terhadap Keputusan Pembelian (Y) adalah sebesar $0.001<0.05$ dan nilai thitung lebih besar dari tabel yakni $3.543>1.996$, sehingga dapat disimpulkan bahwa $\mathrm{H}_{1}$ diterima, yang berarti harga $\left(\mathrm{X}_{1}\right)$ mempunyai pengaruh secara parsial terhadap variabel Y. dan dapat dilihat dari hasil pengisisan kuisioner bahwa responden sebanyak 44 orang (62\%) menyatakan bahwa mereka setuju (memberikan poin 4) pada peryataan nomor 4 bahwa Faktor harga menjadi salah satu pertimbangan dalam bertransaksi dan para responden sebanyak 46 orang $(65,7 \%)$ juga menyatakan mereka setuju pada pernyataan bahwa Harga tiap produk yang dijual memiliki persaingan harga dengan harga jual produk yang sama yang dijual pesaing.

2. Nilai sig. untuk pengaruh kemasan produk $\left(\mathrm{X}_{2}\right)$ terhadap Keputusan Pembelian (Y) adalah sebesar $0.000<0.05$ dan nilai thitung lebih besar dari tabel yakni $4.323>1.996$, sehingga dapat disimpulkan bahwa $\mathrm{H}_{2}$ diterima, yang berarti kemasan produk $\left(\mathrm{X}_{2}\right)$ mempunyai pengaruh secara parsial terhadap variabel $\mathrm{Y}$. dan menurut hasil kuisioner sebanyak 42 reponden (60\%) menyatakan bahwa mereka setuju dengan pernyataan bahwa kemasan pada produk yang dijual memiliki desain kekinian yakni sebanyak 39 responden $(55.7 \%)$ juga setuju dengan pernyataan bahwa Produk UMKM Desa Jotang Beru menawarkan kebutuhan apa saja yang diperlukan dan dibutuhkan oleh pelanggan.

3. Nilai $F_{\text {hitung }}$ diperoleh sebesar $25.311>\mathrm{F}_{\text {tabel }}$ sebesar 3,13 dengan tingkat signifikansi $0,000<0,05$. Karena tingkat signifikansi lebih kecil dari 0,05 maka Ha diterima, sehingga dapat dikatakan bahwa Harga dan Kemasan Produk terhadap keputusan pembelian berpengaruh secara simultan (bersama-sama).

\section{Saran}

Berdasarkan analisa data dan pembahasan pada bab sebelumnya maka saran yang dapat disampaikan:

1. Bagi UMKM Desa Jotang Beru

a. Agar melakukan peningkatan dari segi harga yang lebih kompetitif dan kualitas Kemasan Produk yang lebih baik dengan melakukan riset keinginan dari konsumen dan melakukan penelitian yang lebih akurat lagi.

b. Melakukan riset keputusan pembelian lebih lanjut, karena masih ada faktor-faktor lain yang belum dapat dijelaskan dalam penelitian ini.

\section{Bagi Peneliti Selanjutnya}

a. Bagi pihak yang ingin melakukan penelitian yang sejenis, disarankan untuk meneliti variabel-variabel lain selain harga dan kemasan produk. Karena dari penelitian ini diketahui 58,7\% masih ada faktor - faktor lain yang mempengaruhi keputusan pembelian.

b. Lebih teliti lagi dalam penentuan teori dan pembuatan kuesioner, agar lebih baik lagi dalam hasil penelitian

c. Untuk memperkuat hasil penelitian serupa dianjurkan menambah sampel dan menjelaskan proses pengisian kuesioner dan mendampingi responden ketika mengisi kuesioner tersebut

\section{Daftar Pustaka}

Alma Buchari. 2016 Manajemen Pemasaran dan Pemasaran Jasa

Bhuono, Agung Nugroho, "Strategi Jitu Memilih Metode Statistik Penelitian dengan SPSS", Penerbit Andi, Yogyakarta, 2005.

Daud Denny. 2013 Promosi dan Kualitas Layanan Pengaruhnya Terhadap Keputusan Konsumen Menggunakan Jasa Pembiayaan pada PT. Bess Finance Manado. Volume 1 Nomor 4.

Firdaus Muhammad . 2009 Fungsi Pemasaran dan Pengertian Pemasaran

Ghozali, Imam.”Aplikasi Analisis Multivariat Dengan Program SPSS", Badan Penerbit Universitas Dipenogoro, Semarang, 2009 
Kotler Philip dan Keller Kevin Lane. 2009 Manajemen Pemasaran. Edisi 13 Jilid 2

Lesut, 2015 Analisis biaya produksi dalam ranga penentuan harga jual makanan Ragey Poppy di Tomohon. EMBA, 47

Levy, Michael dan Weitz Barton A. "Retailing Manajemen”, U.s: Irwin McGraw-Hill, Lumpkin, 1998.

Purwanto, "Metodologi Penelitian Kuantitatif untuk Psikologi dan Pendidikan", Pustaka Pelajar, Yogyakarta, 2008
Santoso, Singgih, “Mastering SPSS Versi 19”, Elex Media Komputindo, Jakarta, 2011.

Simamora, Henry. 2000. Akuntansi Basis Pengambilan Keputusan Bisnis, Jakarta: Salemba Empat.

Sugiyono. 2013, Metode Penelitian Kuantitatif Kualitatif dan R\&D

Tjiptono, Fandy. Strategi Pemasaran Cetakan Ketiga, Yogyakarta: Andi Offset, 2011.

Umar, Husein, "Riset Pemasaran dan Perilaku Konsumen", Gramedia Pustaka Utama, Jakarta, 2010. 